\title{
APLIKASI BERBASIS E-COMMERCE SEBAGAI MEDIA PROMOSI TENUN IKAT KABUPATEN TIMOR TENGAH SELATAN
}

\author{
Petrisia Widyasari Sudarmadji
}

\begin{abstract}
:
Kabupaten Timor Tengah Selatan memiliki potensi industri ekonomi dari salah satu tradisi turun-temurunnya yaitu menenun. Hal ini sangat menjanjikan serta mampu memberi manfaat dari segi pendapatan pada masyarakat setempat karena didukung oleh peraturan daerah (PERDA - Kab. TTS) yang mengatur mengenai penggunaan kain tenun ikat sebagai bahan dasar modifikasi pada seragam pakaian dinas pegawai negeri sipil, yang di pakai sekali dalam seminggu. Namun yang menjadi pokok permasalahan, bahwa untuk merancang suatu pemasaran yang luas sehingga hasil produk mereka dapat di lihat dan dibeli oleh khalayak dimanapun berada secara online tentulah sangat tidak memungkinkan karena mereka dihadapkan pada keterbatasan finansial/ dana dan sumber daya manusia. Penelitian ini bertujuan untuk menemukan cara yang lebih efektif dalam memasarkan hasil penjualan tenun ikat dengan jangkauan yang lebih luas menggunakan inovasi teknologi informasi. Target khusus yang akan dicapai adalah meningkatkan kesejahteraan ekonomi dengan implementasi aplikasi rancang bangun berbasis E-Commerce sebagai inovasi teknologi informasi sehingga dapat memenuhi pasar yang lebih luas dan meningkatkan kualitas SDM (Sumber Daya Manusia) perajin sanggar tenun ikat. Metode yang digunakan dalam penelitian ini adalah: action research. Metode ini dipilih karena pada tahap pertama akan dilakukan kajian penelitian (research) terhadap model-model pengembangan yang sudah dilaksanakan dan kemudian berdasarkan hasil kajian itu merumuskan satu model pengembangan inovasi teknologi informasi berbasis E-Commerce yang tepat sesuai kebutuhan. Pada tahap kedua akan dilaksanakan implementasi (action) untuk menerapkan model aplikasi yang sudah diperoleh dari hasil kajian dan perancangan program pada tahap pertama, diikuti dengan revisi untuk menghasilkan model aplikasi terakhir
\end{abstract}

Keywords : Tenun ikat, e-commerce, Basisdata, Inovasi teknologi.

\section{PENDAHULUAN}

Kabupaten Timor Tengah Selatan, memiliki potensi ekonomi dari salah satu tradisi turuntemurunnya yaitu menenun. Menenun merupakan kegiatan rumah tangga yang bersifat tradisi, kemasyarakatan dan ekonomi. Hal ini merupakan salah satu potensi industri yang sangat menjanjikan serta mampu memberi manfaat dari segi pendapatan pada masyarakat setempat karena didukung oleh peraturan daerah
(PERDA - Kab. TTS) yang mengatur mengenai penggunaan kain tenun ikat sebagai bahan dasar modifikasi pada seragam pakaian dinas pegawai negeri sipil, yang di pakai sekali dalam seminggu. Perda tersebut secara langsung mendukung peningkatan produksi kain tenun ikat sebagai komoditi dan kebutuhan pegawai negeri sipil yang berada di Kabupaten Timor Tengah Selatan. Adapun jenis tenun ikat yang beragam yaitu diantaranya BUNA, LOTUS dan 
FUTUS. Itulah beberapa alasan, mengapa tenun ikat Timor Tengah Selatan di hargai dengan harga yang tinggi karena kualitas dan ciri khas yang unik. Selain itu setiap pola dan motif yang ditenun merupakan manifestasi dari kehidupan sehari-hari masyarakat dan memiliki ikatan emosional yang cukup erat dengan masyarakat. Kain tenun ikat yang dihasilkan tidak sekadar menjadi komoditi bahan pakaian semata, tetapi adapun fungsi lain yaitu sebagai busana dalam tari adat dan upacara adat, sebagai mahar dalam perkawinan, sebagai pemberian dalam acara kematian dan sebagai wujud penghargaan, sebagai penunjuk status sosial, dan sebagai bentuk penghargaan bagi tamu yang datang berkunjung. Dengan berbagai fungsi hasil tenun ikat tersebut tentunya menjadi peluang bagi kelompok sanggar tenun yang ada di Kabupaten Timor Tengah Selatan karena dari sektor produksi sebenarnya sudah sangat potensial.

Berdasarkan survey awal di Timor Tengah Selatan, sekarang ini ada 26 kelompok sanggar tenun ikat yang bernaung di bawah satu binaan usaha bersama yaitu " Rumah Tenun Ikat Nekafmese SoE “. Sanggar-sanggar tenun ikat yang tergabung dalam usaha bersama tersebut merupakan usaha yang menitikberatkan aspek produksi sebagai prioritas, dimana kelompok sanggar tenun tersebut merupakan penghasil kerajinan utama yang akan menjual hasil tenunan secara langsung kepada calon pembeli yang berminat. Pada kelompok usaha ini, selain memproduksi hasil tenunan, mereka juga menyediakan layanan jasa pemasarannya kepada calon pembeli pada saat menerima pesanan, mengecek ketersediaan stok, hingga transaksi pembayaran. Pada setiap transaksi pelayanan jasa pemasaran tersebut mulai dari menerima pesanan hingga transaksi pembayaran akan membentuk opini dan minat kepada calon pembeli, apakah pelayanan sanggar tenun ini sudah optimal melayani pembeli atau belum.

Oleh karena itu perlunya ada solusi, agar dapat merancang suatu aplikasi pemasaran berbasis E-Commerce yang dapat secara online melayani transaksi jual beli. Dengan adanya suatu aplikasi rancang bangun berbasis $E$ -
Commerce maka para perajin kelompok sanggar tenun dapat dengan cepat menjalankan transaksi jual beli tanpa harus menunggu hasil produksi tenunan mereka di beli hanya oleh supplier lokal saja. Selain itu membantu kelompok usaha ini terus termotivasi untuk meningkatkan usahanya. Program perancangan aplikasi ini sebagai strategi pemasaran untuk meningkatkan ekonomi dalam upaya mengembangkan inovasi teknologi informasi. Demikian pula untuk mendukung keberlangsungan strategi pemasaran tersebut maka akan di lengkapi dengan pelatihan manajemen kewirausahaan yang terstruktur untuk mengukur keberhasilan aplikasi rancang bangun berbasis E-Commerce ini secara periodik.

Penelitian ini secara khusus bertujuan untuk menemukan cara yang lebih efektif dalam memasarkan hasil penjualan tenun ikat dengan jangkauan yang lebih luas menggunakan inovasi teknologi informasi. Target khusus yang akan dicapai adalah meningkatkan kesejahteraan ekonomi dengan implementasi aplikasi rancang bangun berbasis E-Commerce sebagai inovasi teknologi informasi sehingga dapat memenuhi pasar yang lebih luas dan meningkatkan kualitas SDM ( Sumber Daya Manusia ) perajin sanggar tenun ikat dalam pemanfaatan inovasi teknologi informasi. Urgensi penelitian ini adalah: aplikasi rancang bangun berbasis E-Commerce menggunakan bahasa pemrograman tingkat tinggi untuk mengolah informasi input dan mengeluarkan informasi output, transaksi pemasaran hingga laporan yang bisa di setting per-periodik tertentu. Aplikasi yang menggunakan bahasa pemrograman tingkat tinggi ini di hubungkan dengan aplikasi basisdata (database) yang terdiri dari beberapa tabel yang saling ber-relasi, sebagai media pangkalan penyimpanan data (storage) yang menyimpan setiap inputan data oleh admin maupun pengguna ( user ). Proses input dilakukan oleh admin secara langsung berupa datadata stok kain tenun ikat, harga, motif, ukuran, pemesanan, transaksi pembayaran maupun galeri foto tenun ikat yang disediakan. 


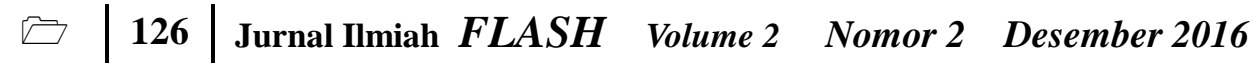

\section{KAJIAN LITERATUR}

Beberapa hasil penelitian tentang rancang bangun aplikasi berbasis e-commerce, diantaranya adalah : secara umum, e-commerce dapat diartikan sebagai proses transaksi jual beli secara elektronik melalui media internet. Menurut Mariza Arfina dan Robert Marpaung (2011) e-commerce merupakan suatu cara berbelanja atau berdagang secara online atau direct selling yang memanfaatkan fasilitas internet dimana terdapat website yang dapat menyediakan layanan. Dalam penelitian mereka berjudul "Pembuatan Website E-Commerce di PT.Batik Rahmawati Surakarta " ditemukan suatu konsep penjualan menggunakan hardware yang secara fisik berbentuk keras yang meliputi keseluruhan bagian dari komputer dan software yang berisi sekumpulan instruksi yang dibuat untuk menjalankan aplikasi yang dikendalikan melalui hardware. Pada penelitian tersebut, data-data penelitian di dapatkan melalui observasi langsung dan wawancara sehingga sekumpulan data sekunder dan primer tersebut dijadikan analisa sistem untuk proses pembuatan e-commerce. Selanjutnya e-commerce menjadikan internet sebagai penghubung interaksi manusia (user) dan komputer dalam layanan penjualan/perdagangan. Internet sendiri sebenarnya berasal dari kata internet work atau koneksi antar dua atau lebih jaringan. Aplikasi e-commerce di akses melalui web browser yang merupakan perangkat lunak untuk menampilkan dokumen HTML. Web browser akan membantu pengguna mengakses halaman web yang di sediakan oleh sebuah web server serta membantu dalam hal navigasi.

Menurut Sidik (2004), HTML (Hypertext Markup Language) adalah salah satu scripting yang dapat menghasilkan halaman website sehingga halaman tersebut dapat diakses setiap komputer pengakses (client). Dokumen HTML inilah yang berisi informasi ataupun aplikasi dalam internet. Penelitian ini menghasilkan aplikasi penjualan yang dapat diakses melalui jaringan internet dengan jangkauan yang luas dan mengandalkan database sebagai pangkalan data dan keamanan data. Tujuan yang diharap- kan pada penelitian ini adalah dapat membantu mempercepat proses penjualan dan pemesanan produk-produk serta transaksi pembayaran secara online dengan calon pembeli dimana pun berada, dalam jangkauan yang luas dan sistem keamanan data yang handal. Dengan menggunakan aplikasi e-commerce ini, maka jelas sekali perbedaan antara sistem lama yang sangat manual dan konvensional dalam proses penjualan yakni pencatatan arsip, dan hanya dibeli oleh supplier lokal saja. Sedangkan dengan adanya aplikasi e-commerce maka proses penjualan tidak terbatasi oleh waktu, tempat dan calon pembeli/supplier. Sehingga turut meningkatkan omset sebagai strategi pemasaran dalam meningkatkan kesejahteraan ekonomi perajin/penjual. Dalam upaya mengembangkan inovasi teknologi informasi pada rumah tenun ikat Nekafmese SoE melalui penjualan/pemasaran hasil tenun ikat menggunakan aplikasi berbasis e-commerce, telah dilaksanakan studi pendahuluan yakni menemukan pemodelan untuk memasarkan hasil tenun ikat. Berdasarkan data-data yang telah dikumpulkan dari visit maupun wawancara, maka data tersebut dapat dijadikan referensi dalam pembuatan aplikasi berbasis e-commerce. Berdasarkan hasil data yang terkumpul kemudian dijadikan analisa sistem kebutuhan untuk proses coding pada aplikasi berbasis e-commerce. Dari studi pendahuluan ini, dapat dirumuskan suatu peta jalan penelitian untuk mencapai tujuan yang ditargetkan adalah sebagai berikut:

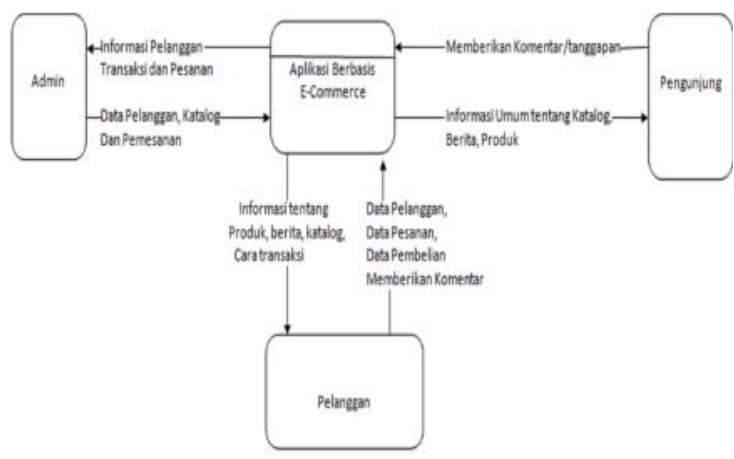

\section{METODE PENELITIAN}

Adapun studi pendahuluan yang telah dilaksanakan berupa survey awal, pada kegiatan 
penelitian ini dan telah di deskripsikan dalam fishbone diagram berikut ini :

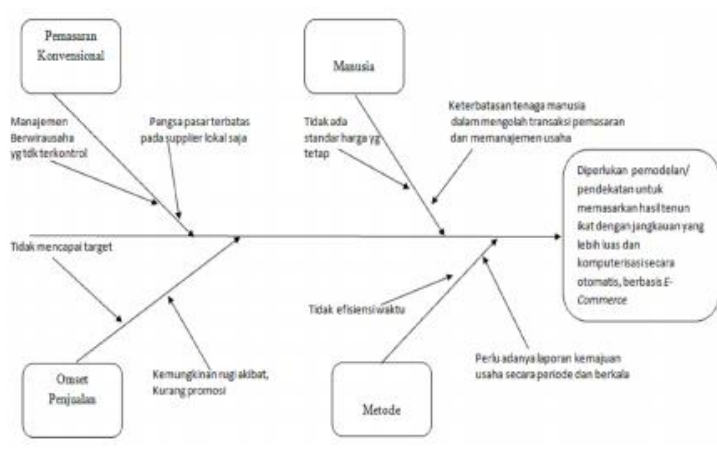

Rencana kegiatan penelitian dan metode yang digunakan

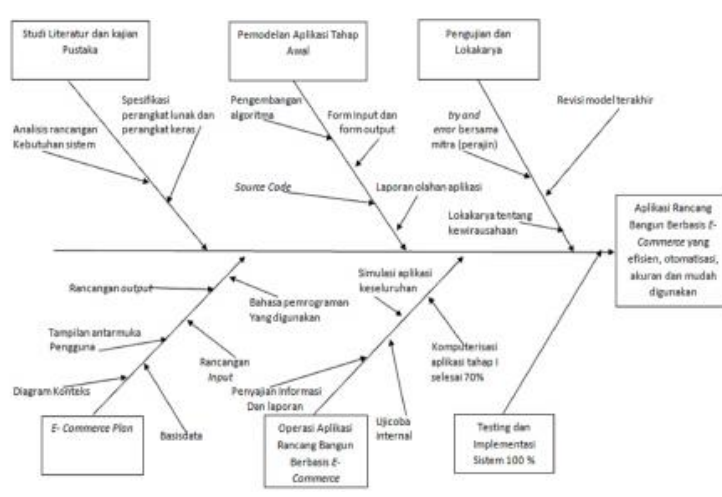

Sejalan dengan tujuan yang ingin dicapai dalam penelitian ini, yakni membuat rancang bangun aplikasi berbasis E-Commerce sebagai strategi pemasaran meningkatkan kesejahteraan ekonomi dalam upaya mengembangkan inovasi teknologi informasi pada rumah tenun ikat Nekafmese SoE, dan kemudian mengoptimalkan aplikasi ini dengan implementasi yang tepat, maka penelitian ini menggunakan action research.

Metode ini dipilih karena pada tahap pertama akan dilakukan kajian penelitian (research) terhadap model-model pengembangan yang sudah dilaksanakan dan kemudian berdasarkan hasil kajian itu merumuskan satu model pengembangan inovasi teknologi informasi berbasis ECommerce yang tepat.

Pada tahap pertama yang direncanakan pada tahun pertama, akan merancang diagram kon- teks, tabel-tabel data yang saling berelasi membentuk suatu basisdata, merancang tampilan antar muka pengguna berupa form masukan (input) dan keluaran (ouput), menentukan bahasa pemrograman yang akan digunakan, merumuskan source code yang digunakan untuk memecahkan kasus pemrograman yang dikerjakan, serta ujicoba implementasi program E-Commerce yang di buat. Kemudian pada tahap kedua akan dilaksanakan implementasi/ tindakan ( action ) untuk menerapkan model aplikasi rancang bangun yang sudah diperoleh dari hasil kajian dan perancangan program pada tahap pertama, diikuti dengan revisi untuk menghasilkan model aplikasi terakhir. Dengan demikian metode action research ini, digunakan bersama-sama antara peneliti dan decision maker (mitra pada rumah tenun ) untuk menentukan masalah, membuat desain serta melaksanakan program-program tersebut untuk menstimulasikan pelaksanaan program penelitian ini kearah yang lebih baik serta lebih menggiatkan implikasi dari berbagai alat untuk mencapai target dan tujuan yang lebih meningkatkan kesejahteraan ekonomi perajin tenun ikat.

\section{HASIL DAN PEMBAHASAN}

Dalam penyelesaian permasalahan Rumah Tenun Nekafmese SoE, penulis memulai tahap analisis dengan mengidentifikasi permasalahan sistem pemasaran produk tenun ikat dan promosi produk yang tersedia, pada sistem yang sedang berjalan sebelumnya. Dengan strategi konvensional yang manual, sehingga manajemen kewirausahaannya tidak terkontrol dengan baik serta pangsa pasar terbatas pada supplier lokal saja. Sistem pemasaran yang konvensional mengakibatkan omset penjualan tidak mencapai target sehingga pengembalian modal usaha sangat sulit dicapai dan mengalami kerugian. Untuk meningkatkan omset penjualan maka dibutuhkan suatu pemodelan rancang bangun berbasis e-commerce sebagai media penjualan dan promosi ke jangkauan yang lebih luas dan menarik. Namun di suatu sisi, penulis harus mengupayakan pemberdayaan soft-skill 


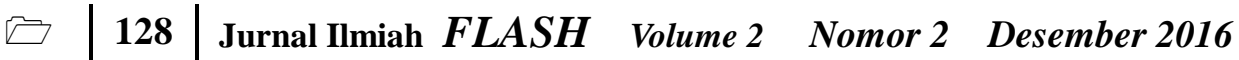

pemakai aplikasi ini dengan mengadakan pelatihan dan lokakarya untuk meningkatkan sumber daya manusia yang lebih baik lagi di Rumah Tenun Nekafmese SoE. Adapun tahapan yang dilaksanakan dalam penelitian ini telah mencapai tahapan-tahapan yang diuraikan sebagai berikut :

Pelaksanaan penelitian diawali dengan studi literatur dan kajian pustaka untuk melengkapi referensi dalam menentukan pemodelan dan perancangan yang sesuai dengan permasalahan yang dihadapi Rumah Tenun Nekafmese SoE. Dari berbagai studi literatur dan kajian pustaka, maka penulis mendapatkan data primer dan data sekunder secara kualitatif. dengan adanya informasi sebagai rencana kebutuhan mitra : Rumah Tenun Nekafmese SoE maka penulis menentukan bahan rumusan rancangan pemodelan aplikasi rancang bangun berbasis $e$ commerce serta spesifikasi perangkat lunak dan perangkat keras yang akan digunakan. Rancangan yang disusun mengalami sedikit perubahan dari usulan proposal dalam tampilan interface serta penyajian informasi karena disesuaikan dengan kebutuhan pengguna aplikasi $e$-commerce dan ketersediaan anggaran yang difasilitasi.

Adapun rancangan yang telah di buat untuk pemodelan ini dan sebagai penjelasan yang akurat penulis membuatkan sebuah flowchart program tentang alur kerja sistem yang di kerjakan :

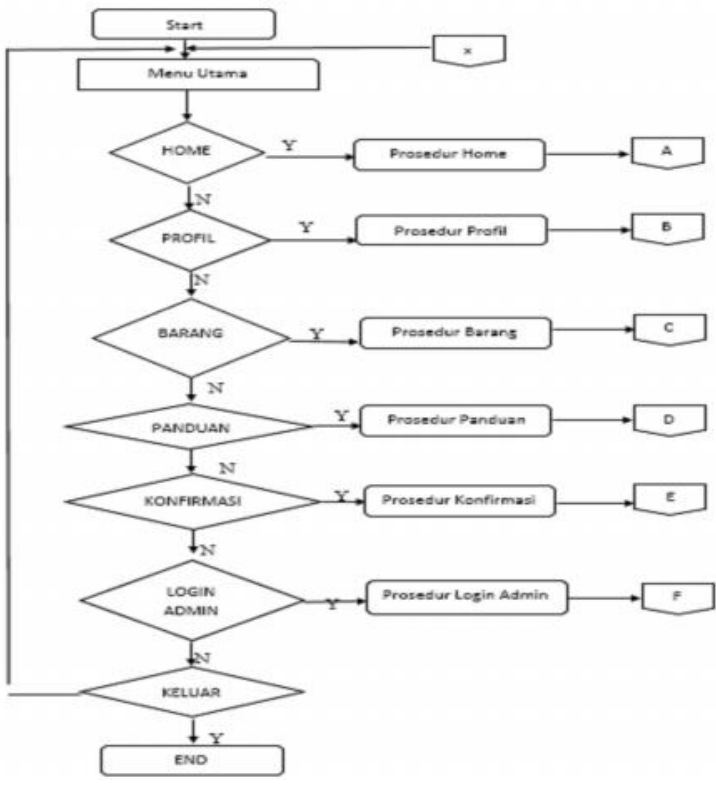

flowchart menu utama

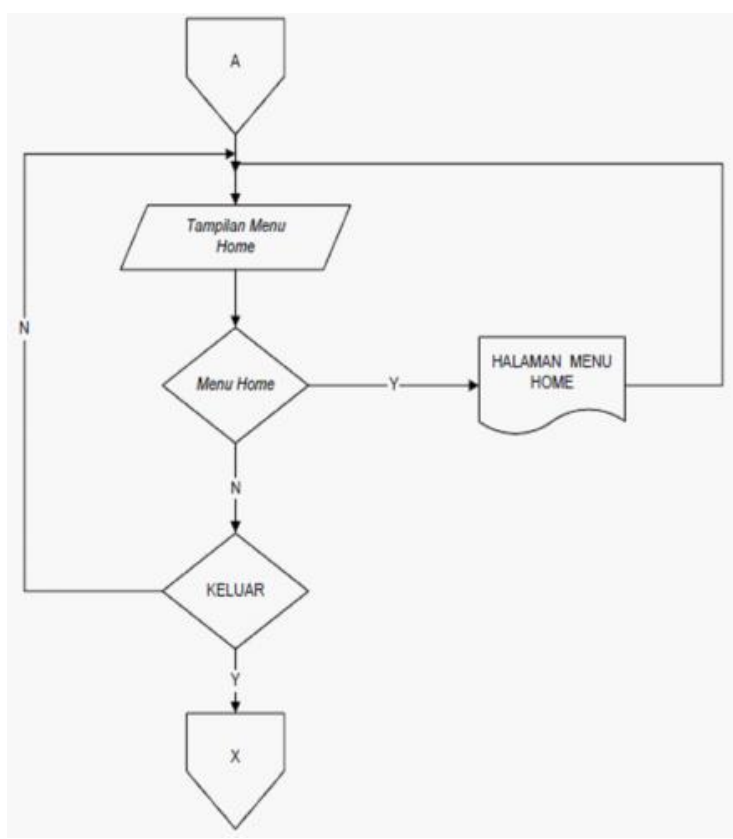

flowchart menu home 


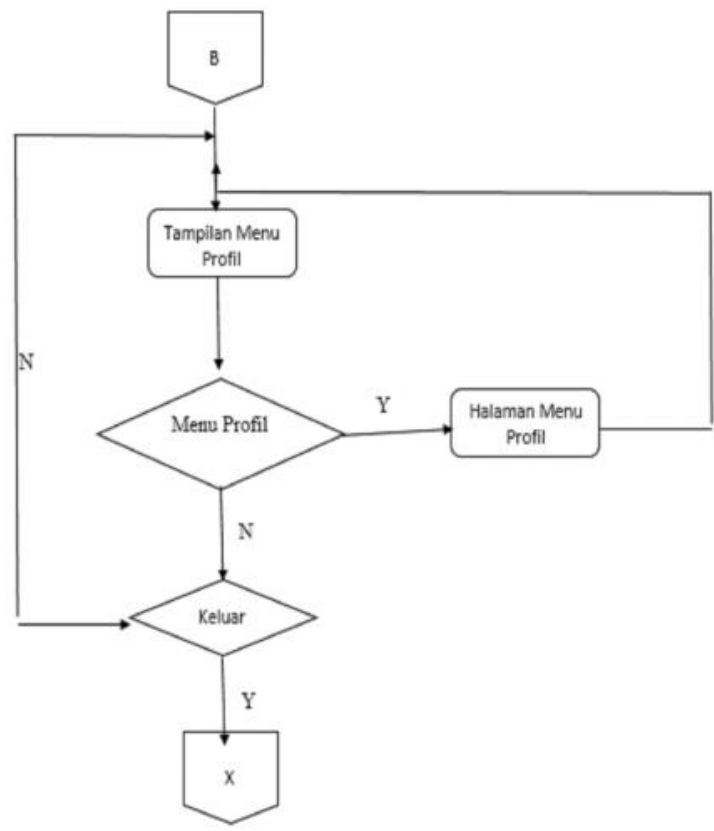

aplikasi e-commerce. Adapun site map dalam website/ aplikasi e-commerce yang penulis usulkan adalah sebagai berikut :

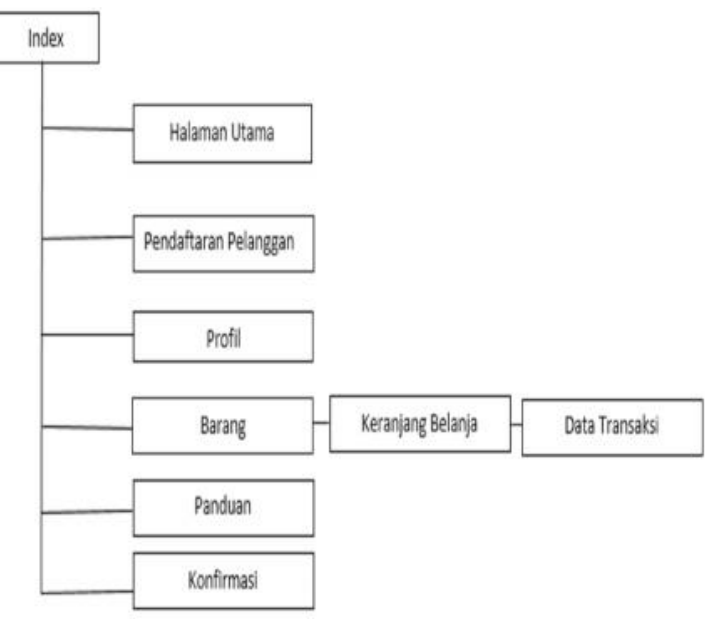

Site Map Pada User

flowchart menu profil

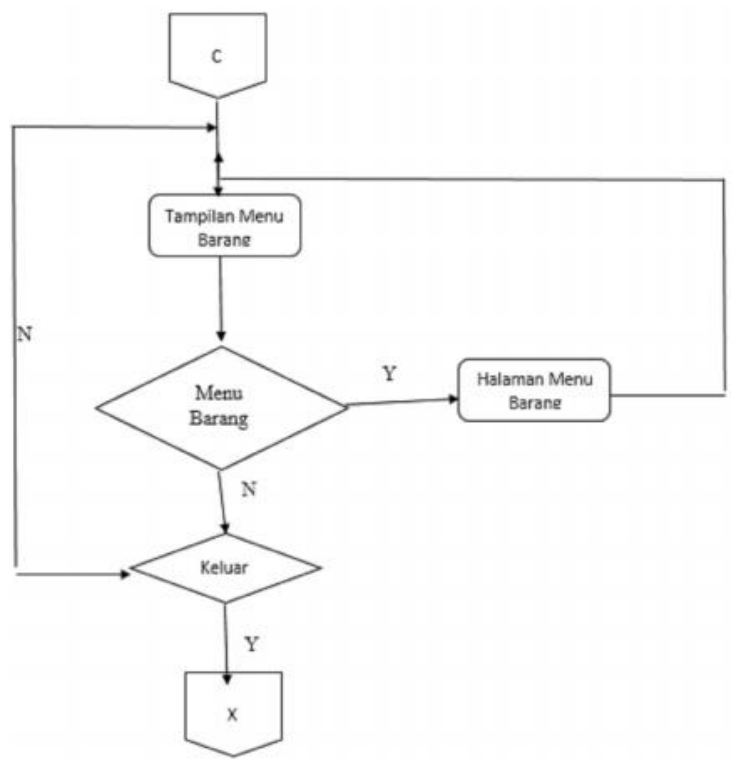

flowchart menu barang

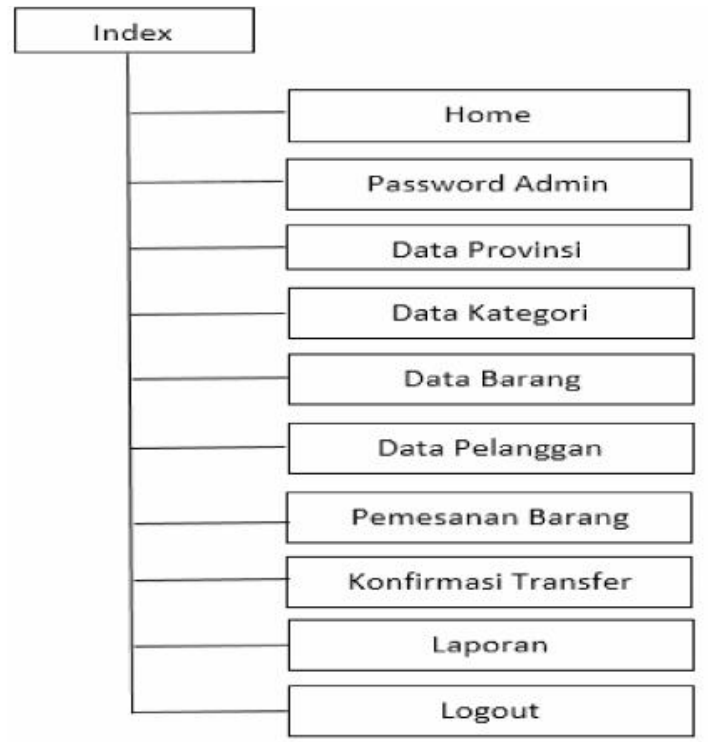

Site Map Pada Admin

Site Map

Site map di buat untuk menerangkan alur sebuah websitel aplikasi e-commerce yang diusulkan yang berfungsi untuk memudahkan pengunjung dalam memakai fasilitas website/ 

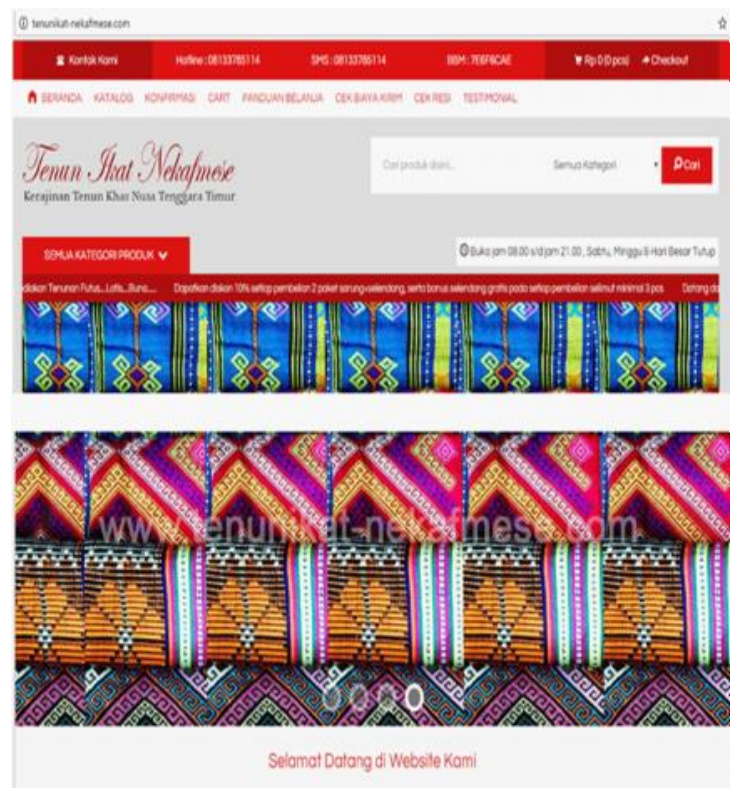

Gambar Aplikasi e-commerce Rumah Tenun Nekafmese SoE

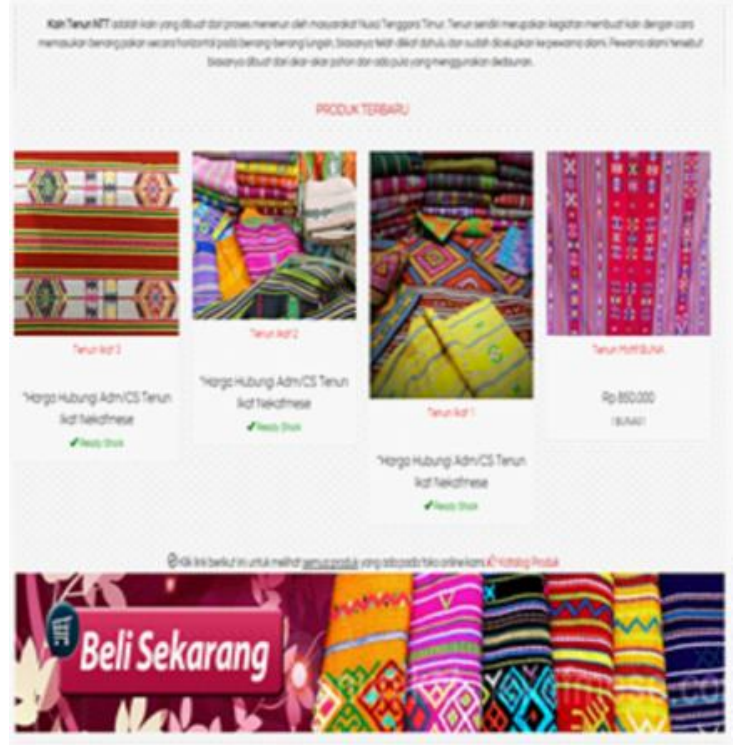

Effacebook (3) indogan

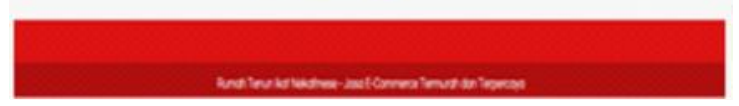

Menu Katalog Pada Aplikasi E-Commerce Rumah Tenun Ikat Nekafmese SoE

\section{KESIMPULAN}

1.Rancang Bangun aplikasi berbasis Electronic Commerce (E-Commerce) merupakan inovasi teknologi yang mendukung kegiatan perekonomian, karena mampu memanfaatkan jaringan komputer dan media internet sebagai fasilitas dalam proses pembelian dan penjualan produk, jasa dan informasi yang dilakukan secara elektronik.

2.Dengan adanya aplikasi berbasis E-Commerce, maka rumah tenun ikat Nekafmese SoE dengan mudah mempromosikan produk-produk tenun ikat yang dipasarkan dan motifmotif tenun yang terbaru dengan kualitas terbaik agar menarik perhatian para konsumen/ pengunjung situs.

3.Aplikasi berbasis E-Commerce ini dapat membuka peluang bisnis lebih luas lagi, karena produk tenun ikat yang dijual tersebar lebih luas dan mampu meningkatkan produktivitas dan kesejahteraan ekonomi

\section{DAFTAR PUSTAKA:}

Ade, Kemal, dan Sularto, Lana (2001). "Introduction To E-Commerce" . Lembaga Komputerisasi Universitas Gunadarma : Jakarta.

Abdul Kadir (2003). "Pengantar Sistem Informasi”. Andi Yogyakarta : Yogyakarta.

Abidarin Rosidi dan M Suyanto (1999). "Manajemen". UPT Penerbitan AMIKOM : Yogyakarta.

James A.F Stones Alfonsus Sirait (1994). "Manajemen Edisi Kedua". Erlangga : Jakarta.

M. Suyanto (2003). "Stretegi Periklanan Pada E-Commerce Perusahaan Top Dunia”. Andi : Yogyakarta.

Mamduh M.Hanafi (1997). “Manajemen”. UPP AMP YKPN : Yogyakarta.

Onno W. Purbo dan Aang Arif Wahyudi (2001). "Mengenal E-Commerce". Elex Media Komputindo : Jakarta

Phillip Kotler (2000). “Manajemen”. Prenhalindo : Jakarta.

Richardus Eko Indrajit (2001). "Kiat E-Commerce dan Strategi Bisnis di Dunia Maya". Gramedia : Jakarta. 